Doi: $\underline{\text { dx.doi.org/10.17921/2525-5320.2016.209-211 }}$

\title{
ALTERIDADE: UMA CONSTRUÇÃO DA APRENDIZAGEM SIGNIFICATIVA NO ENSINO SUPERIOR
}

\author{
Antonio Oliveira Djú* - UNOPAR
}

Palavras-chave: Alteridade. Ensino Superior. Educação. Aprendizagem Significativa. Diálogo.

\section{INTRODUÇÃO}

Quando se pensa o tema de educação no ensino superior, surge a preocupação de discutir, além dos conteúdos, a aprendizagem significativa. O desafio que aparece dentro deste contexto, marcado pelas relações multiculturais, é como facilitar essa aprendizagem de forma significativa.

Com a democratização do ensino superior, houve um ingresso significativo das diferentes classes sociais e culturais do Brasil no ensino superior, que até então era para as elites. Isso exige uma diversificação, da parte da universidade e do docente, pela forma de atendimento e de ensinagem.

O ideal de uma educação seria formar pessoa para a construção do ser, enquanto social e humano, e permitir que ela se libertasse da passividade e se tornasse autônoma, capaz de transformar a si e sua sociedade em sujeito.

Aprofundar o conceito de alteridade e sua aplicação no ensino superior surge como necessário e inevitável para construir o conhecimento e facilitar o convívio com as diferenças sociais nas universidades.

São objetivos deste estudo: Compreender a alteridade dentro do processo de ensino nas universidades, marcada pela relação docente-discente, ambos em busca de conhecimento; trazer a discussão de alteridade em seu aspecto sócioantropofilosófico; problematizar o espaço do ensino superior como produto da alteridade; e identificar aprendizagem significa como fruto da alteridade, baseado no diálogo.

\footnotetext{
*E-mail: antoniodju@yahoo.it
} 


\section{MATERIAL E MÉTODOS}

Este estudo será uma pesquisa bibliográfica. Far-se-á um aprofundamento das leituras em obras dos autores: Martin Buber (Eu e Tu - 1974); Lea Anastasiou (Processos de ensínagem na universidade; pressupostos para as estratégias de trabalho em aula - 2009); Nadja Hermann (Ética \& Educação: outra sensibilidade 2014); Paulo Freire (Educação e Mudança - 1986; Educação da Autonomia: saberes necessários à prática educativa - 2001). Outras obras e artigos, estruturados por autores consagrados no campo da educação, antropologia e filosofia, serão também consultados.

Como o debate científico educacional sobre alteridade no ensino superior é recente, a pesquisa vai se apoiar nas noções de interdisciplinaridade e transdisciplinariedade como chave para aprimoramento individual e social da alteridade perante as diversidades socioculturais no ensino superior.

\section{RESULTADOS E DISCUSSÃO}

Falar da alteridade no ensino superior é falar de uma relação permeada pelo social, no qual a pessoa aprende. E aprendizagem significativa orienta e estimula processos internos de desenvolvimento.

Espaço do Ensino superior é um espaço apropriado para abrir-se ao outro, através do diálogo. Diálogo, na condição de Igualdade entre os dois sujeitos do conhecimento, pressupõe liberdade e autonomia.

Aprendizagem significativa não acontece, a menos que o discente dela participe. Há um esforço de alguns docentes de integrar entre si o processo de ensino, pois isso auxilia o discente a construir um quadro teórico-prático global mais significativo e mais próximo de sua realidade.

A partir desses dados, o resultado que se chega é que quanto mais os sujeitos do conhecimento se abrem um ao outro, dentro do processo do ensino, menos conflito se tem, mais social se torna e mais intensa acontece aprendizagem significativa. E isso se chama alteridade.

\section{CONCLUSÃO}

O ensino pautado na alteridade é um processo construído pela relação intensa 
entre os sujeitos do conhecimento. Em meio ao processo interativo, acontece compreensão dos contextos e dos elementos que adquirem o significado.

No processo de diálogo, como metodologia, a problematização deve ser dialética. Quanto mais o docente e discente se abrem ao diálogo, aos diferentes pontos de vista dos interlocutores, mais continuarão aprendendo. E isso se torna aprendizagem significativa.

\section{REFERÊNCIAS}

ANASTASIOU, L. Processos de ensinagem na universidade: pressupostos para as estratégias de trabalho em aula. Joinville: Univille, 2009.

BUBER, M. Eu e tu. São Paulo: Moraes, 1974.

FREIRE, P. Pedagogia da autonomia: saberes necessários à prática educativa. São Paulo: Paz e Terra, 1996.

FREIRE, P. Extensão ou comunicação? Rio de Janeiro: Paz e Terra, 1983.

HERMANN, N. ética \& educação: outra sensibilidade. Belo Horizonte: Autentica, 2014.

LEVINAS, E. Entre nós: ensaio sobre a alteridade. Petrópolis: Vozes, 2004.

MENDES, Z.P. Martin Buber e a relação eu/tu: inversão e recíproca de inversão nas relações. 2012. 49 f. Monografia (Especialização em Filosofia Clínica) - Instituto Packter \& Instituto Interseção, São Paulo, 2012. 